\title{
Apparatus Resource Development Strategy at the Merauke Regency Regional Civil Service Agency
}

\author{
Everistus Rikardus1, Muh. Tang Abdullah², Rakhmat ${ }^{3}$ \\ 1,2,3 Faculty of Social Science and Political Science, Universitas Hasanuddin, Makassar. \\ Email: everistusmaster2020@gmail.com
}

\section{ARTICLE INFO}

Keywords:

strategy, apparatus, training and education

Kata kunci: strategi, aparatur, pendidikan dan pelatihan

How to cite: Rikardus, E., Abdullah, M. T. Rakhmat. (2020). Apparatus Resource Development Strategy at the Merauke Regency Regional Civil Service Agency. JAKPP (Jurnal Analisis Kebijakan dan Pelayanan Publik, 6(2), 113125.

\section{ABSTRACT}

This study aims to (1) describe and analyze the condition of existing apparatus resources in the Merauke Regency Regional Personnel Agency; and (2) describe and analyze the apparatus development strategy in the Merauke Regency Regional Personnel Agency. This research applies a qualitative approach. The informants involved included: (1) Head of the Regional Civil Service Agency; (2) Subdivision of the Strategy of the Regional Civil Service Agency Resources; and (3) a number of training alumni employees. Data collection techniques are interviews, observation, study of literature and documentation. Data analysis techniques are carried out through data reduction, data presentation and data verification. The results showed that the implementation of education and training, especially in the Merauke Regency Regional Personnel Agency, had been effective, although there were still some improvements that needed to be made so that the results of the training could be maximized as expected. Employees are the most important resource in a public organization. Good employees who meet the qualification standards can only be obtained through effective recruitment efforts. The implementation of education and training in the Merauke Regency Regional Personnel Agency is good because based on the results it shows starting from training materials, good and effective delivery methods in the training process, facilities and infrastructure to support training activities, skilled presenters, learning process according to standard procedures, proportion of time and the method of implementation was working well and effectively.

\footnotetext{
Abstrak

Penelitian ini bertujuan untuk (1) menggambarkan dan menganalisis kondisi existing sumberdaya aparatur di Badan Kepegawaian Daerah Kabupaten Merauke; dan (2) menggambarkan dan menganalisis strategi pengembangan sumberdaya aparatur di Badan Kepegawaian Daerah Kabupaten Merauke. Penelitian ini menerapkan pendekatan kualitatif. Informan yang dilibatkan meliputi: (1) Kepala Badan Kepegawaian Daerah; (2) Subbag Strategi Badan Pengembangan Sumberdaya Badan Kepegawaian Daerah; dan (3) beberapa pegawai alumni diklat. Tehnik pengumpulan data adalah wawancara, observasi, studi kepustakaan dan dokumentasi. Tehnik analisis data dilakukan melalui reduksi data, penyajian data dan verifikasi data. Hasil penelitian menunjukkan bahwa pelaksanaan pendidikan dan pelatihan khususnya di Badan Kepegawaian Daerah Kabupaten Merauke sudah efektif, meskipun masih ada beberapa yang
} 
JAKPP (Jurnal Analisis Kebijakan dan Pelayanan Publik)

6(2), 113-124: Apparatus Resource Development Strategy...

perlu dilakukan pembenahan-pembenahan agar hasil pelaksanaan diklat bisa maksimal sesuai yang diharapkan. Pegawai merupakan sumber daya yang paling penting dalam organisasi publik. Pegawai yang baik dan memenuhi standar kualifkasi hanya dapat diperoleh melalui upaya rekrutmen yang efektif. Pelaksanaan diklat di Badan Kepegawaian Daerah Kabupaten Merauke termasuk baik karena berdasarkan hasil menunjukan mulai dari materi pelatihan, metode penyampaian yang baik dan efektif dalam proses diklat, sarana dan prasarana sebagai penunjang kegiatan diklat, pemateri yang terampil, proses belajar sesuai standar prosedur, proporsi waktu dan metode pelaksanaan sudah berjalan baik dan efektif.

\section{Introduction}

The emergence of a new paradigm of bureaucracy needs to be a priority in carrying out bureaucratic reform, especially in terms of planning and developing apparatus resources (Civil Servans / ASN). The current government bureaucracy should implement and develop a learning organization system in the ASN development program. In essence, a learning organization is a climate that can encourage and accelerate individuals, groups, or organizations to continue learning and always apply critical thinking processes in understanding what should be done and why to do it (Soetjipto \& Ardiyanti, 2006).

It has become a common phenomenon in this country, that almost all elements of government leadership place the development of apparatus resources at the top of their work program. However, in its implementation, this apparatus resource development is not running as it should or in other words it is just a slogan. This is due to insufficient budget (if we don't want to say none at all) which they allocate for apparatus resource development. They will prioritize budget allocations for physical development, because the results will be more visible to the community than apparatus resource development, the results of which will only be visible several decades later. Especially in the era of reform like today, where their existence in that position or position will depend on their respective constituents.

As a subject in implementing human development, human capital should be assessed on several sides, the emphasis is on core competence, capability, and learning process. To improve employee performance and productivity, there are several important things that must be considered, such as knowledge, capability, skills, attitudes, behavior and ethics, and habits. Meanwhile, in career coaching, it is necessary to set a clear coaching system, both in terms of rank, position, task maturity, training and education. Besides that, every personnel must know clearly about the career pattern that will be taken, therefore every agency should have a clear career pattern system.

The Regional Civil Service Agency $(B K D)$ of Merauke Regency as a government organization wants its officials to be able to provide the resources, they have in carrying out development and also in terms of services. However, the BKD institution itself finds many problems in carrying out apparatus resource 
development such as: minimum service standards in service in the personnel sector, lack of personnel capable of carrying out tasks, the level of competence and professionalism attainment is still very minimal to support the vision and mission in the field of personnel, is still low. Awareness in the implementation of main duties and functions (TUPOKSI) and facilities and infrastructure that still needs to be improved in order to support the smooth running of personnel duties.

Education and training (DIKLAT) are an effort to develop the quality and competence of human resources in the apparatus. Education and training for apparatus has a significant influence in increasing employee competence, because this is a learning process that is designed and carried out systematically and continuously to improve the competence of the apparatus so that they are able to carry out their job duties professionally. However, on the other hand, there are other problems that occur in the implementation of education and training in the form of learning activities that are more formal in nature so that learning participation and obedience to the discipline of training participants do not reach an optimal level of awareness. The implementation of education and training often becomes inappropriate, when the implementation of education and training is based only as an annual routine activity and is not a necessity in increasing the competence of the participants, so that when the training ends, the competencies to be achieved will also end.

Ideally, a training program is able to produce competent personnel who can later show a better professional attitude and skills than before attending the training. However, the reality that is currently happening, an education and training which in its implementation involves so many positive ideas and activities aimed at improving the abilities and skills of its participants, ultimately only becomes a gathering place and a vehicle for momentary entertainment for the participants without realizing that there is something very important. important that has been overlooked by them, namely to become an individual whose abilities are increasing.

Thus, considering the importance and strategic position and development of the competence and quality of human resources in an organization / agency, the authors are interested in examining how the strategy for developing human resources for apparatus in the Regional Personnel Agency of Merauke Regency.

\section{Literature Review}

\section{Human Resources}

According to Nawawi (2000) in Suliatiyani and Rosidah (2003), what is meant by human resources are humans who work in an organization (also called personnel, labor, employees or employees), human potential as an organizational driving force in realizing its existence and potential which is an asset and functions as capital (non-material / non-financial) in a business organization, which can be realized into physical and non-physical real potential in realizing the existence of the organization. 
Human resources are the abilities or potentials possessed by humans in the form of minds, emotions, motivation, skills, attitudes and behaviors that are used for the benefit of individuals, their organizations, and their environment. According to Siagian (2003) human resources is actually the responsibility of two parties, namely; first, line managers in all levels of the organization, second, the work unit that manages human resources, meaning that every manager is an human resources manager as well.

\section{Apparatus Resource Development}

Employees or apparatus in government organizations are the most valuable organizational assets, because with all the potential they have, employees can continue to be developed, so that they can be more efficient, their performance will be more optimal to achieve organizational goals.

Education and training is one of the main approaches in developing human resources. Education and training is carried out as an approach, because it has a strategic role in the achievement of organizational goals, both government and private. On the other hand, it is also an individual success for an employee's career and can improve his professional quality.

According to Dessler (2005), training is a process of teaching new employees about the basic skills they need to carry out activities. While Ivancevich (1992) defines training more deeply, the emphasis is on a dynamic and strategic conceptual framework, which is a systematic process of changing employee behavior within a framework of objectives to improve organizational goals.

Human resource development aims to produce a logically linked and comprehensive framework for developing an environment in which employees are encouraged to learn and develop. Human resource development activities include traditional training programs, but the emphasis is more on developing intellectual models and promoting organizational, team and individual learning.

Training and development is a shared responsibility and especially top management (leadership) and receives support from various parties. The leadership has responsibility for the general policies and procedures needed to implement a training and development program. For this reason, leadership commitment is very important in order to take place effectively, both from planning, processes and objectives of training and development.

\section{Strategic Management}

Strategic management allows an organization to be more proactive than reactive in shaping its own future. This allows an organization to initiate and influence activities and thus strive to control its own goals.

According to David (2002), strategic management can be defined as a crossfunctional decision that enables an organization to achieve its objectives. According to Pearche and Robinson in Ayas (2018), strategic management is a collection of decisions and actions that result in the formulation and application of strategic principles designed to achieve organizational goals. 
The strategic management process is based on the belief that the organization should continuously monitor internal and external events and trends so as to make changes in a timely manner. In order to maintain its sustainability, the organization must be able to wisely recognize and adapt to change.

According to Robbins in Salusu (2006) strategy can be defined as the determination of the goals, long-term basis, goals of a company, and acceptance of a series of actions, as well as the allocation of resources needed to carry out these goals. Strategy is the art of using the skills and resources of an organization to achieve its goals through effective relationships with the environment in the most favorable conditions (Salusu, 2006).

In the organization there are several types of strategies, such as what Koteen and Higgis argue, as for the types of strategies referred to are; (1) Organizational strategy (corporate strategy), this strategy is related to the mission, goals, values, and new strategic initiatives; (2) program strategy, this strategy pays more attention to the strategic implications of a particular program; (3) Resource support strategy, this strategy focuses on maximizing the use of available essential resources in order to improve organizational performance; (4) Institutional strategy (institutional strategy), the focus of this strategy is to develop the organization's ability to carry out strategic initiatives (Salusu, 2006).

Several things that must be considered in creating a civil servant development strategy in government organizations both internal and external according to Notoadmodjo (2003) and Said (2019) are as follows: Internal factors include such as; (1) the vision, mission and objectives of the organization; (2) strategy for achieving organizational goals; (3) nature and types of activities; (4) the type of technology used. And external factors include such as; (1) government policy; (2) socio-culture in society; (3) development of science and technology; (4) global environment. Logically, the importance of developing apparatus resources (ASN) is a conditio sine guanon, which must exist in every government organization both in the central and regional governments.

\section{Research Methods}

This research uses a qualitative approach. This research was conducted at the Merauke Regency Regional Civil Service Agency (BKD), Papua Province, and lasted for three months. Data and research focus information were obtained from 7 informants. Key informants were the Head of the Merauke Regency Regional Civil Service Agency and the Head of the Sub-Chart of the Apparatus Development Strategy for the Regional Civil Service Agency. Additional informants are employees totaling four alumni of the education and training (Diklat) carried out so far. The collection technique was carried out through structured and in-depth interviews with informants, direct observation, tracing documents related to apparatus resource development $(A S N)$ in Merauke Regency. Data analysis techniques through: data reduction, data presentation, and validity of data and information obtained in the field. 


\section{Results and Discussion}

Regional staffing bodies (BKD) have the task of formulating policies in the field of employment in their working areas, as well as carrying out other duties related to employment including recruitment and recruitment. Whereas the function of this BKD is documentation in the field of personnel including data on government employees, regional government personnel planning, staffing policy making, executing activities in the field of government personnel, disseminating personnel information, determining salaries related to the welfare of government employees, to executing, monitoring, and evaluating government personnel administration.

\section{Current Condition of Merauke District Personnel Agency}

Based on the view that the Merauke Regency Regional Personnel Agency has made improvements to its employee work system. This is important, that by making breakthroughs and changing work patterns, it shows that there is a better understanding in the implementation of apparatus development, especially in the Regional Civil Service Agency of Merauke Regency. As a quote from an interview with an employee of the Merauke Regency Regional Personnel Board regarding the current condition of human resources, he stated that:

"In human resource development, the pattern of bureaucratic work structures leads to functional work patterns, changes in work patterns from bureaucracy to more administrative to functional patterns which emphasize the initiative and creativity of the state civil apparatus as globalization demands which require several dimensions regarding bureaucratic behavior, behavior. organization and individual apparatus behavior. These three behaviors lead to one goal (good governance) of good governance and that is an ideal set out in the vision and mission of the elected Regent for 2015-2021 as outlined in the Regional Medium-Term Development Plan (RPJMD) and is a noble ideal. of all State Civil Apparatus working within the Merauke district government. "

In improving employee resources within the Regional Civil Service Agency, it is of course important to know how employees respond to the ASN Law in Merauke Regency, one of the informants from the $B K D$ Merauke Regency, in his interview excerpt said:

"Regulations that are used as a reference. Those were the main basic civil service laws and now the ASN Law and this is now a problem, such as the current problem in employee placement in Merauke Regency because of the issuance of the ASN Law. The authority of local governments is like in pasung. So there are 6 functions that cannot be carried out at the lower level of the government at the provincial level and the city district level which are regulated in article 18 paragraphs 6 and 5 , so there are two things that have an impact on this bureaucracy, namely, first is the biggest impact because Pemilukada politics and the birth of a government of reciprocation and the second is revenge. "

The results of the interview above show that the rules that become the reference are Law no. 43 of 1999 regarding the Principles of Civil Service and 
which changed to Law no. 5/2014 on State Civil Servants and this is the problem. For example, there is now a problem in recruiting employees in Merauke Regency due to the issuance of Law no. 5 of 2014. New problems also arise as a result of the politics of the Regional Head General Election and the birth of a government of reciprocation or revenge, the rule of law states that lower regulations cannot conflict with higher regulations, so on this basis the law must be annulled if it is based on a review of laws and regulations. applicable.

\section{Human Resources Development Strategy for the State Civil Apparatus of the Regional Civil Service Agency of Merauke Regency}

The human resource development strategy in the Merauke Regency Regional Civil Service Agency is not only limited to education and training programs (Diklat), but also applies a coaching strategy through disciplinary enforcement, this is supported by the opinion of Sarwono (1993) that human resource development strategies include: education, training, coaching, recruitment and system changes.

\section{a. Education and Training Program (Diklat).}

Training aims to develop individuals in the form of increasing skills, knowledge and attitudes, while through education aims to increase work ability, in the sense that development is formal and career-related.

Based on the answers of informants about the importance of education and training to be implemented in general, the answer is important. This is as answered by one of the Secretary of the BKD Merauke Regency:

"For us, training is very important, because through training we are taught many things regarding work procedures, governance, and others which really help us understand our work every day. The benefits are very pronounced because the development of science is very fast, if we don't follow it, it will be left behind and the impact is on our performance in community service."

Thus, according to the above opinion it is important to carry out education and training. Because education and training are needed to support proficiency and skills at work.

Thus, according to the above opinion it is important to carry out education and training. Because education and training are needed to support proficiency and skills at work:

"The implementation of the training is always preceded by an analysis of the needs of employees so that the training is not in vain but is right on target. For example the need for computer mastery, based on the initial analysis this is very much needed and the average employee is still less knowledgeable about computers, so computer training is carried out for all officers. The results are very pronounced, because employee performance is better and faster. Thus it can be judged that the education and training programs provided are in accordance with the needs of employees." 
From the human resource development strategy of the Merauke Regency Regional Personnel Board through education and training (Diklat), it is divided into three forms namely (1) Leadership Training, (2) Technical Training, and (3) Functional Training.

- Leadership Education and Training

Merauke District Civil Service Agency in leadership training shows that employee participation in leadership training has not been fully based on an analysis of training needs assessment both the needs of employees and their organizations. So, what happens is that the participants who take the leadership training are not clear in their next position placement.

Based on the results of interviews with informants, there are several phenomena that cause the inadequate use of leadership training in structural positions. One of the informants who was successfully interviewed was the Head of the Personnel Development Division of the BKD Merauke Regency, said that:

"The use of leadership training is not optimal yet because employee participation in leadership training is not used as a reference or consideration for placing someone in a structural position or as a reference for employee career development (promotion). Conversely, in most cases the participation of an employee in the Leadership Training is intended only to meet the requirements for employees who have held structural positions "

In addition, based on the results of an interview with an employee of the BKD Merauke Regency, he said that:

"One of the problems that causes the low utilization of leadership training in structural positions is due to political considerations. The replacement and even removal of an employee from his structural position really depends on the political will of the currently serving regional head "

- Technical Education and Training

Interview with the informant of the Head of the Education and Personnel Division of the Merauke BKD, quotations from the interview said that:

"The technical competence of employees is a very important part in supporting their performance and work, without technical skills it is difficult for us to improve employee performance. As a staffing agency that oversees all employees in Merauke Regency, we as staff in this agency should have deeper capabilities. technical matters, especially in the implementation of administrative tasks "

Furthermore, he stated:

"The apparatus must be professional in carrying out their duties and jobs, through technical training we encourage the apparatus here to better master the main duties and functions of their institution."

Based on the results of interviews with the Education and Personnel Division of the Merauke BKD, it focuses on improving technical competence and professionalism in terms of carrying out its duties, especially the main functions of 
the agencies they oversee. Professional employees or government officials have a significant and positive effect on the progress and improvement of the quality of the organization. This is due to the fact that government employees act as determinants, planners, implementers, and supervisors of government administration. In addition, the lack of professionalism of the apparatus in the management of public services has resulted in a lack of willingness to participate in development planning and a sense of public apathy towards the government which has resulted in a decrease in the level of performance, which in turn creates distrust.

The Merauke Education and Personnel Sector focuses on improving technical competence and professionalism in terms of carrying out its duties, especially the main functions of the institutions they oversee. Professional employees or government officials have a significant and positive effect on the progress and improvement of the quality of the organization. This is due to the fact that government employees act as determinants, planners, implementers, and supervisors of government administration. In addition, the lack of professionalism of the apparatus in the management of public services results in a lack of willingness to participate in development planning and a sense of public apathy towards the government which results in a decrease in the level of performance and ultimately leads to distrust.

\section{- Functional Education and Training}

By participating in educational and training activities, employees are expected to be able to improve the skills and attitudes of employees to carry out their duties, because this will support employees in carrying out their duties.

Regarding this, it can be seen from the statement of the Head of Education and Training regarding the improvement of skills and attitudes of employees after attending education and training, along with the statement:

"After attending education and training, employees have better skills and attitudes based on their duties and functions. The attitude changes the most then skills, meaning that their views and insights can be seen from the good attitude shown."

Another view that is in line with the above statement is the Head of the Transfer and Rank Division, who said:

"Before they participated in training and education activities, the skills and attitudes of these employees were normal, but after participating in the training they had broader insights and were accompanied by better attitudes and skills."

From the results of the interview above, it can be said that the quality of work in the skills and attitudes of employees has seen changes before and after participating in education and training activities, where the change in question is an increase in skills accompanied by an increase in employee attitudes such as discipline and loyalty.

b. Development through Discipline Enforcement 
Discipline fostering can be done by enforcing discipline in government agencies, in this case the Regional Civil Service Agency (BKD) of Merauke Regency. Efforts that can be made in enforcing discipline following the morning and evening roll call, signing the attendance list, after entering working hours must be in the work room. Based on the informants' answers about the existence of disciplinary rules, there are generally answers that exist and the disciplinary rules are very clear. This is as conveyed by one of the staff, he said that:

"the disciplinary regulations here are actually very clear because they exist and are always conveyed, even posted in each section room."

With this discipline rule, employees cannot do their job at will. Then about filling in the attendance list before and after working hours. According to the staff who were also interviewed said that:

"this is always conveyed to all existing employees. The leadership reminds employees every day, because even though they are present, if they do not fill in the attendance list before and after working hours, attendance is not counted, this is certainly a loss for the employee himself. "

This means that not only are there very clear disciplinary regulations but also that it is socialized to employees. And then the existing employees often fill in the attendance list before and after working hours. This can be seen in the answers of the informants in the interview, where all of them answered frequently. According to him, they need to ask permission when leaving the workplace before working hours are finished, because if this is not done then they are considered absent from work. This is as conveyed by the head of the Transfer and Rank Division of the BKD Merauke Regency:

"employees here obey the rules, they are unlikely to leave the office if they are not given permission by the above officials, especially during working hours or when a lot of work is being done, because if they do In this case, they will be given the most severe sanctions, that is, they are considered not to come to work on that day"

Discipline fostering can also be done by giving sanctions or punishments to employees who are not disciplined. The results of an interview with the Secretary of the BKD Merauke Regency, said:

"If you violate the rules that have been set, sometimes you will be sanctioned by the superior. Disciplinary violations committed by employees receive appropriate sanctions and in accordance with statutory regulations. Sometimes double standards apply when imposing sanctions"

In the implementation of Education and Training at the Regional Personnel Agency of Merauke Regency, training participants are given information about the importance of the role of Civil Servants, as the main element of human resources in the apparatus who have a very important role in determining the success of governance and development administrators. In addition, information is also given training on how the figures of Civil Servants who are able to play this role, namely civil servants who have competencies as indicated by attitudes and behaviors that are full of loyalty and obedience to the nation, state, moral and 
mentally good, professional, aware of responsibility. he answered as a public servant and able to be the glue of the unity and integrity of the nation.

To realize the figure of ASN, strategic guidance is needed, namely through Education and Training. These efforts lead to an increase in attitude and spirit of service oriented towards the interests of the community, nation, state and homeland, technical competence, managerial and leadership, efficiency, effectiveness and quality of the implementation of tasks carried out in a spirit of cooperation and responsibility in accordance with the environment and organization.

Improving the quality of the resources involved in the training has an important role in helping to develop the skills of training participants. Human Resources has a very strategic position in the organization, meaning that humans play an important role in carrying out activities to achieve better goals and conditions. From the research results, it was found that there was an increase in the quality of Human Resources both in terms of working ability, thinking ability, as well as increasing skills and attitudes of employees who took part in Education and Training activities at the South Sulawesi Province Education and Training Agency. This is in line with the research of Yoman (2016) and Hayat (2014), which concluded that the increase in personnel resources (ASN) through education and training can be seen from changes in attitudes and skills. The role of education and training is very much needed, especially after training participants take part in the training, because to know the development of employees requires continuous evaluation in order to monitor its progress. Professional and disciplined apparatus are used as driving force to improve the quality of apparatus resources.

\section{Conclusion}

Based on the research findings, the authors can draw the conclusion that the implementation of education and training, especially in the Regional Personnel Agency of Merauke Regency, has been effective, although there are still some improvements that need to be done so that the results of the implementation of education and training can be maximally as expected. ASN is the most important resource in public organizations. The ideal ASN that meets the qualification standards can only be obtained through effective recruitment efforts.

The strategy for developing apparatus resources through Education and Training at the Regional Personnel Agency of Merauke Regency is good because based on the results it shows starting from training materials, good and effective delivery methods in the training process, facilities and infrastructure to support education and training activities, skilled presenters, learning process according to standard procedures, the proportion of time and method of implementation has worked well and effectively with what the informants felt. Through the implementation of training at the Regional Personnel Board of Merauke Regency, both through leadership training, technical training and functional education and training have been able to improve the performance and work productivity of 
ASN. Even so, the strategy for developing apparatus resources in the Regional Personnel Agency (BKD) of Merauke Regency is not only implementing the Education and Training program in developing its apparatus but also guidance that is carried out through the application of ASN discipline.

\section{References}

Arikunto, Suharsimi. 1993, Manajemen Penelitian, Cetakan kedua. Jakarta: PT. Rineka Cipta.

Ayas, Dafa Romi. 2018: “Analisis Strategi Pembangunan Sumber Daya Aparatur Dalam Meningkatkan Kinerja Pegawai Di Badan Kepegawaian Serdang Bedagai". Jurnal Publik. Volume (4). http://jurnal.dharmawangsa.ac.id

David, Fred R. 2002. Manajemen Strategis: Konsep dan Teori. Jakarta: Prenhallindo

Dessler. Garry. 2005. Manajemen Sumber Daya Manusia. Jilid 1. Edisi Kesembilan. Jakarta: PT. Indeks Kelompok Gramedia.

Dwiyanto, Agus. 2002. Reformasi Birokrasi Publik Di Indonesia. Yogyakarta: PSKKUGM.

Handoko, T Hani. 1993. Manajemen.Yogyakarta: BPFE.

Ivancevich. John, M. 1992. Human Resources Management Foundations of Personel. USA: Richard D.Irwn Inc

Nawawi, Hadari, 2000. Manajemen Sumber Daya Manusia Untuk Bisnis yang. Kompetitif. Yogyakarta: Gajah Mada.

Notoatmodjo, Soekidjo, 2003, Pengembangan Sumber Daya Manusia, Jakarta: PT. Rineka Cipta.

Pemerintah Indonesia. 2014. Undang-Undang Nomor 5 Tahun 2014 tentang Aparatus Sipil Negara. Jakarta: Kemenkeu RI.

Robbins, Stephen P. 1994. Teori Organisasi Struktur Design dan Aplikasi. Jakarta. Arcan

Said, Achmad Lamo, 2019. “Evaluasi Pengembangan Pegawai Di Pemerintahan Daerah (Studi Kasus di Kolaka Utara)". JAKPP. Volume 5 No. 1, Juni. http://journal.unhas.ac.id/index.php/jakpp/article/view/6451

Salusu, J. 2006. Pengambilan Keputusan Strategik Untuk Organisasi Publik dan. Organisasi NonProfit. Jajarta: Grasindo.

Sedarmayanti. 2007. Manajemen Sumber Daya Manusia Reformasi Birokrasi dan Manajemen Pegawai Negeri Sipil. Bandung: Rafika Aditama

Siagian, Sondang, P. 2003. Organisasi Kepemimpinan Dan Prilaku Administrasi, Jakarta: Gunung Agung

Soetjipto dan Ardiyanti, 2006. Menggapai SDM Optimal: Kinerja Produktivitas, Kreativitas. Jakarta: Lembaga Manajemen FEUI 
Volume 6 No. 2, Desember 2020

pISSN: 2460-6162. eISSN: 2527-6476

Sulistiyani dan Rosidah. 2003. Manajemen Sumber Daya Manusia, Konsep, Teori dan Pengembangan Dalam Konteks Organisasi Publik. Yogyakarta: Graha Ilmu 